\title{
Neistá Bratislava: medzi iniciáciou a imitáciou (Ivan Horváth: Laco a Bratislava)
}

\section{Vladimíra Mravcová}

\author{
MRAVCOVÁ, V.: Insecure Bratislava: Between Initiation and Imitation \\ (Ivan Horváth: Laco a Bratislava [Laco and Bratislava]) \\ SLOVENSKÁ LITERATÚRA, vol. 68, 2021, no. 3, pp. 255-262 \\ DOI: https://doi.org/10.31577/slovlit.2021.68.3.5 \\ ORCID ID: 0000-0003-3059-7605V
}

Key words: Bratislava as a space

of initiation, city of ideals and

scepticism, emotional education

\begin{abstract}
The article focuses on the image of Bratislava during the first Czechoslovak Republic as presented in Ivan Horváth's novella Laco a Bratislava. The city is viewed through the prism of the protagonist's revaluation of his ideals and as a site of the possibilities it provides on the personal and social level. The movement of the hero through the city bears traces of imitation of certain literary traditions that creatively make use of motives typical for education or disillusionment novels as well as discourses bearing initiation function. In this way, Bratislava becomes a space of emotional education. The hero's striving for self-actualisation is paralleled with Bratislava's ambitions to develop, modernise or imitate the style of big cities. His attitude towards the city is analogous with a relationship with a woman. Bratislava is portrayed as a lover, maiden, dark lady or a double. The atmosphere with which the city is invested mirrors the development of a romantic relationship. At first, it is dreamy, postcard-like, melancholic, drawing on memories and history and invested with a hope for a future. The loss of certainty in the romantic relationship, revelation of the city's social inequalities and the impossibility of self-actualisation are reflected in its changed atmosphere. Disillusionment and nostalgia prevail as the protagonist is leaving Bratislava, hoping for a return which, however, cannot be granted. The city is also portrayed through glimpses of scenes in cafés and exotic air of its oriental features.
\end{abstract}



prístup k mestskému toposu, ked'že v slovenskej literatúre prevažuje antiurbánne písanie, kde zvykne byt' mesto démonizované a situované do protikladu k vidieku (Minár 1998). Uvádza sa tiež, že Horváth v nej predstavil Bratislavu ,,ako prítažlivé európske vel'komesto $s$ dávnou a pestrou históriou i s bohémskou prítomnostou. Tento obraz bol povzbudzujúci, inšpirovaný nádejami mladej republiky, že všetko sa bude d'alej slubne rozvíjat'“ (Mikulová 1989: 102). Protagonista novely Laco, ktorý prichádza do mesta študovat', je spočiatku síce očarený urbanizmom a modernizáciou Bratislavy, no jeho optimistický pohl'ad je v perspektíve rozprávača skôr predmetom reflexie, ktorá je s ironickým odstupom postupne problematizovaná. Dobové nádeje mesta sa tak prepájajú s nádejami mladého človeka a výrazom tohto spojenia je pre prózu príznačný mestsko-psychologický paralelizmus: „Ó, mesiac, ktorý postriebruješ Dunaj a klameš ho, vy svetlá utešujúce sa vlastnou žiarou a kaviarne stá bruchá molochov, príd'te všetci a vysvetlite Lacovi, čo je život. [...] Očakával niečo a zabudol, žev dvadsiatom storočí sa divy dejú len v kine“ (Horváth 2010:131). Horváthova Bratislava tak získava charakter mesta nádejí a ich prehodnocovania nielen na úrovni kolektívnych ilúzií, ale aj v osobnej sfére. Pre mladíka Laca sa totiž stáva iniciačným priestorom citovej výchovy, ktorý možno vnímat' ako odraz silnejúceho dobového prílevu mladých l'udí z vidieka do mesta za štúdiom. Lacovej ceste za poznaním predchádza pocit osudovej nevyhnutnosti pohybu, ktorý má povahu nutného, no prirodzeného chodu vecí po vzore prírody, prirovnaného k vode „Váhu, ktorá ticho plynúc, sa oddávala s rozkošou svojmu neznámemu osudu“ (Horváth 2010:102). Motív cesty aj naratívne postupy Horváthovej prózy odkazujú na tradičný žáner románu výchovy, skúšok, vývinu, zrenia či stratených ilúzií, ${ }^{1}$ ktoré sa aktualizujú ako modifikované iniciačné prvky spojené nielen s prežívaním subjektu, ale sú naznačené aj v charaktere mesta-v jeho ambícii rozvíjat'sa. Sebarozvoj či sebatvorba subjektu tak predstavuje paralelu s Bratislavou, ktorá sa v súlade s novou štátnost'ou buduje architektonicky aj kultúrne.

Mesto sa pre prichádzajúceho stáva mýtickou „zemou zaslúbenou“, opradenou romantickou ilúziou, cez ktorú Laco vníma Bratislavu ako znovu nájdenú milenku. S lyrickou túžbou po splynutí s okolím či s pocitom, že sa deje niečo významné (,Smrek výnimočne skoro ráno vstal, aby mohol napísat'svoju najlepšiu báseñ “; Horváth 2010: 105), zachytáva obraz ranného prebúdzania mesta, v ktorom sa všetko dáva do pohybu a plynie spolu s ním jedným smerom: „Bratislava sa hýbala [...] ponoril sa do prúdu ludí, ktorý sa hrnuli s ním staničnou cestou a chcel každému okoloidúcemu stisnút' ruku“ (Horváth 2010: 105). Úvodné výjavy mesta nadobúdajú avantgardný charakter, v ktorom sa prelínajú prvky vitalistickej radosti s futuristickým nadšením pre pohyb. Dynamickú atmosféru mesta umocňujú

1 Citovú výchovu vnímam v zmysle flaubertovskej línie románov výchovy v spoločnosti a následnej dezilúzie, ale aj vol'nejšie, ako spoznávanie seba prostredníctvom citovej skúsenosti so svetom, teda iniciáciu v zmysle dozrievania. Iniciačné prvky si budem všímat' na základe toho, ako ich charakterizuje Daniela Hodrová v práci Hladanie románu, kde sleduje ich premenu v rámci výchovných či deziluzívnych románov. Hodrová tiež zdôrazňuje, že v 20. storočí má iniciačná štruktúra charakter tkaniva, ktoré iniciačnými motívmi prerastá text, respektíve znaky iniciačného románu podliehajú ambivalentnej sémantike textu, svojrázne sa deformujú či nadobúdajú torzovitý tvar (Hodrová 1989: 196-197). 
i obrazy stavebného ruchu, vel'kých lešení či murárov na Štefánikovej ulici, ktorá sa napriek okolitému pracovnému zhonu javí v očiach protagonistu sviatočne, „,akoby sa bola vyzdobila“ (Horváth 2010: 105) práve na jeho privítanie. Štefánikova ulica ako hlavná tepna mesta spája železničnú stanicu s centrom, do ktorého Laco smeruje ako do iniciačného priestoru spojeného s mestskými ambíciami či ideálmi. Zastaví sa až pri divadle, kde stojí celú hodinu.

V tomto časovom intervale je zachytená podstata prvej fázy Lacovho vnútorného nastavenia pri stretnutí s mestom: divadlo tu nepredstavuje len kultúrne ustálený symbol snenia či ilúzií, ale spolu s počiatočným očarením mestom sa dostáva do vzt'ahu s tradíciou deziluzívnych románov, kde bolo týmto spôsobom podla Daniely Hodrovej štylizované celé mesto (Hodrová 1994: 107). Ako súčast' odkazov na iniciačné diskurzy možno vnímat' aj postavu Lacovho kamaráta Igora, ktorý ako obyvatel' Bratislavy nadobúda črty zasvätitel'a: zoznamuje Laca nielen s kaviarenským a nočným životom mesta, ale aj s osudovou ženou, do ktorej sa Laco zamiluje. Igor sa javí ako velmi zbehlý a sebavedomý mladík, Laco ho vníma ako budúceho prezidenta budúcich Spojených štátov európskych. Vyzná sa v boxe a pikantnej literatúre, používa odborné výrazy týkajúce sa dostihov a Laco pri ňom nadobúda pocit cambridgeského študenta. V jeho prítomnosti cíti ,tlkot Európy“. Igor reprezentuje úsilie priblížit' sa k vel'komestskému štýlu života podobne, ako to možno vnímat'v charaktere prvorepublikovej Bratislavy, konkrétne v poetistických obrazoch, v ktorých je nezadržatel'ný tok života prirovnaný k šampanskému na Montmartri alebo ohnivá hra na tenisových kurtoch v Petržalke k sútaži o pohár mesta New York. Tento všesvetový obraz Bratislavy vytvára dojem, akoby sa jej obyvatelia usilovali napodobnit', imitovat' väčšie či prestížnejšie mestá, ako na to v rámci výskumu staršej cestopisnej literatúry a bedekrov o Bratislave poukazuje Jozef Tancer napríklad v súvislosti s viedenským libertinizmom či módnymi trendmi z Viedne a ich vplyvom na vtedajší Prešporok (Tancer 2013: 236-239).

Problematika napodobňovania, sústredená okolo postavy Igora s funkciou zasvätitel'a, sa rozvíja nielen na úrovni imitácie vel'komestského štýlu života, ale vystupuje aj v oblasti lúbostnej tematiky, v ktorej Igorovi možno prisúdit' úlohu prostredníka takzvanej trojuholníkovej túžby, ako ju charakterizuje René Girard na príklade bovaryovskej či donkichotovskej tradície: ak sa istý stav javí ako nasledovaniahodný pre iného človeka, stáva sa tento človek prostredníkom, ktorý podnecuje túžbu u d'alšieho jedinca, pričom takáto túžba podl'a druhého sa niekedy kríži aj s túžbou byt' druhým (Girard 1968: 9-49). Trojuholníková túžba je naznačená v Lacovom rozhodnutí zamilovat' sa do Igorovej kamarátky Želky krátko na to, čo ju Igor v jeho očiach vyzdvihne a tiež vyjadrí túžbu po nej. Prítomnost' romantických alúzií v Horváthovej próze konštatuje i Jana Kuzmíková v prípade ironických odkazov na konvenčné literárne pravidlá stvárňovania lásky a ich modernistické variácie či v nadväznosti na ,,romantický sládkovičovský diskurz, v ktorom sa zohl'adňujú aj dávne archetypálne súvztažnosti Panny a Zeme“ (Kuzmíková 2006: 99). Perspektíva mesta tak korešponduje s perspektívou vo vztahu, ako to možno vnímat' v momente situovanom na výstižné miesto s panoramatickým výhl'adom, pravdepodobne vo vilovej štvrti na Palisádach, ${ }^{2} \mathrm{kde}$

2 Laco odprevádza Želku domov cez Koziu ulicu, ktorá vedie z historického centra mesta do vilovej štvrte na Palisádach. 
258 sa Laco z balkóna vily svojej priatel'ky Želky dojíma nad Bratislavou. Vyzdvihuje minulost' mesta, $v$ dekadentne ladenej clivote za starým vznešeným svetom vníma krásu so špinavostou, v ironickej oslave honby za ziskom evokuje pocit rozkladu hodnôt (hmyz, banky, zvada) a v zániku (fialový západ) možno vnímat' odkaz na avantgardnú vieru vo vznikanie nového sveta:

„Hl'ad', i nad Bratislavou tkvie niečo, čo by bolo možno nazvat'duchom dejín a čo ju robí krásnou a špinavou. Ked'pozriešn n hrad, predstav si Rozgonyiho, hrdého obhajcu, a Jiskru, ako ho oblieha, ich dcéry a zemanov, ktorí boli do nich zamilovaní. [...] Pozri na ten ruch v uliciach, to je ruch hlavného mesta Slovenska, teda vraj nás slovenský ruch podl'a mena. Sláva ti bud', mesto naše, plné hmyzu, nádejí, bánk a zvady. Možno tá milovat' a nemilovat', som však len úbohý študent, ktorý verí v budúcnost'a má rád fialový západ, z ktorého klići zmŕtvychvstanie“" (Horváth 2010:120).

Pohl'ad na mesto zhora, zvýraznený patetickým ladením, je tradične spájaný s nádejou a víziami, cez ktoré v prípade uvedenej pasáže presvitá ironická skepsa, signalizovaná aj v modálnych výpovediach ako možno či vraj. Bratislava ako mesto v rovine možnosti, neurčitej prítomnosti a prianí, že by niečo byt'mohlo, no nie je to isté, sa spája s jednou z čŕt stredoeurópskeho priestoru, ako ho vníma Jiří Trávníček, ktorý konštatuje, že o strednej Európe možno hovorit' v konjunktíve a jeho rozmerom je, ,ž̌e koncepty střední Evropy jsou bud'budoucnostními vizemi a projekcemi, nebo nostalgickými vzpomínkami a elegickými nářky nad ztracenou minulosti" (Trávníček 2009: 303-304). Atmosféra možného, ale neistého priestoru preniká pomedzi úvahy o možnostiach mesta a dotýka sa aj úvah o vlastnej sebarealizácii či smerovaní vzt'ahu so Želkou. Výjav na balkóne totiž korešponduje s Lacovou pozíciou vo vztahu: nie je vo fáze dobývania, stvárnenej napríklad v okamihoch, ked' Laco obletuje vilu z ulice, čo možno asociovat' s romantickým obrazom trubadúra pod balkónom svojej milej, ale fázou, ked'je už spolu so Želkou na balkóne a ked' sa už o ňu nemusí snažit'.

Vzt'ah Lacovi postupne zovšednieva a aj na Bratislavu sa začína pozerat' triezvejšie. Priestor pre osamelé rozjímanie mu vytvárajú prechádzky ulicami či nábrežím, zatial'čo miesta socializácie ako korzá a kaviarne nadobúdajú črty pohlcujúcich priestorov, v ktorých zabúda nielen na čas, ale aj na oddanost' vo vzt'ahu k Želke. Bratislava už nie je len paralelou k žene, ale aj jej konkurenciou. V tomto duchu nadobúda črty poetistickej hravosti, chuti užívat' si či podobu eroticko-nezáväzných výjavov:

„Hrával sa často karty v kaviarňach, vadil sa a chodils Igorom po korze, hl'adajúc dievča so žltým klobúkom. Predtým nemyslel na iné dievčatá, len na Želku, teraz však, ked'si bol istý, mohol si to dovolit. [...] Svet okolo neho bol plný novín, biliardov a spevu a on kvôli tým veciam zanedbával Želku“ (Horváth 2010: 124).

Kaviarenský život v medzivojnovej Bratislave je v Horváthovej próze zobrazený rovnako, ako naň neskôr vo svojich memoároch spomínali spisovatelia a umelci, ktorí ho zažili. Miestom stretávania umeleckej bohémy boli najmä kaviarne Astória a Reduta. Horváth odkazuje i na súdobý generačný spor medzi mladými, moderne orientovanými spisovatelmi na jednej strane a volaním po 
kontinuite s tradíciou na strane druhej (napríklad zo strany Štefana Krčméryho). 259 Tento moment však výraznejšie rozvíja v próze Život s Laurou (1948), ktorú umiestňuje do totožného kaviarenského prostredia Bratislavy v medzivojnovom čase. Prelínanie moderného a tradičného v novele Laco a Bratislava prebieha aj na úrovni architektúry mesta, v ktorom sa na pozadí historických pamiatok odrážajú obrazy civilizačného pokroku a architektonickej modernizácie: novopostavené budovy a ich funkcionalistický charakter či futuristický ruch ulíc, kde sa električka preteká s automobilom. Laco si všíma stavby predstavujúce pohyb v oblasti vedy či kultúry, zaznamenáva aj výstavbu budovy Univerzity Komenského a s ňou spojenú skepsu študentov, presvedčených o tom, že jej stavba sa nikdy nedokončí. S budúcnostou mesta sú v Lacových pozorovaniach spojené najmä banky, ktoré ako všeobecné symboly úspechu pôsobia aj v dôsledku ich stvárnenia, teda s impresionistickým (luministickým) dôrazom na svetlo a evokáciou zlatistých odleskov: „Domy chytali nenásytné lúče slnka a zdobili sa pyšne nimi, najštastnejšie boli nové budovy bánk, tým sa ušlo najviac" (Horváth 2010:143).

Do popredia sa dostáva aj téma prehodnocovania vlastných možností uspiet' a spolu s ňou aj Lacovo prehodnocovanie vnímania mesta ako mesta sociálnych nádejí, programov či vízií. Prispieva k tomu aj vztahová skúsenost' so Želkou, ktorá sa za neho ešte nechce vydávat', pretože je príliš mladý a má pocit, že jej po finančnej stránke nemá čo ponúknut' (Horváth 2010:140). Lacov pohl'ad sa tak zameriava na výjavy naznačujúce karierizmus vládnucich tried či hierarchické rozvrstvenie spoločnosti mesta, $\mathrm{v}$ ktorom ,,pred divadlom a pri Dunaji smejúce sa slúžky vozili v kočíkoch nádej budúcnosti, nádejných ministrov, meštáanostov" (Horváth 2010: 143).

Pocit krivdy spôsobujú Lacovi najmä muži v strednom veku, ktorých charakterizuje ako tých, čo už majú ,,majetok, ale žiadneho ohňa v sebe, nevedia už, čo je láska, ale mysel'majú plnú vypočitavosti“ (Horváth 2010: 141). Pre tento ambiciózny postoj je príznačný obraz biliardových hráčov, v ktorom honba za ziskom vyhráva nad mladost'ou s atribútmi citového vzplanutia, rojčenia, ale je aj príčinou neschopnosti uplatnit' sa vo svete zameranom na finančný úspech: „Jeden z nich hral dobre, to bol zaiste prokurista zo Živnostenskej banky. Tí ostatní nevedeli nič, lebo to boli študenti, ktorí milovali. Laco zavrel oči. A očakával dievča, ktoré príde predávat' hodvábne pančuchy“ (Horváth 2010: 130).

Lacov postoj sa však vzd'aluje od predstavitel'ov „milostného pragmatizmu“, ktorého známou reprezentáciou je napríklad Miláčik Guya de Maupassanta. Je opät' naznačený v jeho pohl'ade na priestorové usporiadanie Bratislavy: „nezaujímala ho však už natol'ko, lebo bola skoro celkom vertikálna“ (Horváth 2010: 123).V súlade so symbolickým charakterom priestorov v Horváthovej novele by sa dala vertikála vnímat ako línia vzostupu a pádu, príznačná pre tragédiu a spojená $\mathrm{s}$ ambíciou stúpat' po spoločenskom rebríčku k všeobecne akceptovanej forme usporiadania života. Takéto ambície nachádzajú svoje uplatnenie najmä v žánroch Bildungsroman a románu dezilúzie, s ktorými Horváth konverzuje aj v rámci odkazov na sviatok študentov, inšpirovaný knihou Alexandra Grina, kde červené plachty symbolizujú študentské nádeje, vieru v sny a zázraky. V Lacových pozorovaniach sa zvyknú objavovat' $v$ podobe impresionistických výjavov, no po jeho vytriezvení z opojenia ich nahrádza pohlad na melanchóliu Dunaja, kde ,nebolo lode, ba ani len jednej plachetnice s červenou plachtou" (Horváth 2010: 127). 
Vertikálny pohyb úniku do sveta snov a následné vytriezvenie je síce deziluzívnou tendenciou prózy, no nedotýka sa pragmatických ciel'ov. Lacov pohyb je pokusom o harmóniu s mestom, do ktorého prišiel, aby spoznával umenie, kultúru a hlavne aby miloval. Jeho vyrovnávanie sa s realitou je preto bližšie stredoeurópskemu charakteru: prejavuje sa najmä v subverzívnom postoji voči neosobnému vyššiemu usporiadaniu vecí či vo vedomí, že nie všetko má jednotlivec vo vlastných rukách (Svatoň 2017: 106-114).

Pasívnejší, no napokon zmierlivý postoj volí aj vo vztahu k Želke. Po rozchode hl'adá útechu, a tak ho Igor zasväcuje do nočného života Bratislavy. Chodia všade tam, kde hrá cigánska kapela, do záverečnej vysedávajú v kaviarňach Dunaj a Terézia alebo v Secessionke, kde hráva dámska kapela pre hudobne netalentovaných. V perspektíve rozprávača nie je hedonistický spôsob prežívania mesta výsledkom tradičnej optiky mravného úpadku, ale chápavého, i ked' ironického pohl'adu na istú fázu citovej výchovy v živote mladého človeka, po ktorej môže príst' precitnutie.

Laco, unavený spoločenským hýrením, zažíva pocity osamelosti. Tento stav mu reprezentuje symbolisticky ladená Kapitulská ulica, kde má izbu s výhladom na Dóm. Ide o jednu z najstarších ulíc, ktorá sa zvykla označovat aj ako srdce Bratislavy. V nasledujúcom úryvku zastupuje Lacovo srdce: „Laco stál pri okne, dival sa na Kapitulskú ulicu a na svoje srdce. Oboje bolo opustené, l'ud'mi i láskou, ulicou dýchal chladný vietor, len mrazil nádeje, ktoré chceli rozkvitnút'. [...] Žil a nevedel, že žije, díval sa bezmyšlienkovite von oknom a chcel sa modlit" (Horváth 2010: 142-143). Lacov výber miesta pre bývanie ponúka viaceré analógie s jeho správaním: romantické zákutia vytvárajú kulisu i paralelu k jeho rojčivosti, potreba modlit'sa prichádza len na mieste, ktoré bolo predovšetkým sídlom kňazov. Pamät ulice sa tiež spája so začiatkom korunovačnej cesty, ktorá zas v kontexte Lacovho pocitu zlyhania vyznieva ako ironický kontrast odkazujúci k tradícii deziluzívnych románov. V podobnom duchu sa nesie aj dekadentne štylizovaná Bratislava premenená z panny čakajúcej na svojho milenca na démonizovanú ,čiernu pannu, ktorá smúti za milencom, ktorého sama odohnala" (Horváth 2010:142).

Zjavovanie sa mesta ako panny tiež pripomína iniciačný rozmer novely, stvárnený aj ako stopa po citovej skúsenosti v mestskom prostredí v podobe naivného gesta - potreby Laca ,zotriet'srdce, ktoré vyryl na lavičku pri Dunaji“ (Horváth 2010: 121). Lacova záluba v prechádzkach popri Dunaji anticipuje tiež jeho postupne silnejúcu túžbu vydat' sa v smere toku rieky a vidiet' more, čo vytvára obraz Bratislavy ako prechodného mesta a spája ju s toposom križovatky kultúr, v ktorej sa prelína východ so západom. Okrem mnohých citácií a odkazov na západoeurópsku kultúru má Horváthova Bratislava aj nádych orientálnej atmosféry. Zvýrazňuje ju nielen prítomnost' cigánskej muziky v kaviarňach, ale aj opisy židovskej štvrte v Podhradí s ortodoxným charakterom:

„Pred ním sa otvárali malé uličky geta, židia spajesmi a v dlhých kaftanoch chodili okolo, dívali sa na neho podozrivo a vyhýbali sa mu. [...] Dnu medzi starými hábami, predvojnovými pohl'adnicami, zemiakmi a nádejami na bohatstvo sedeli starí židia a čítali Talmud. [...] Laco šiel d'alej, myslel na čiernooké židovské dievčatá, ktoré v tých domoch bývajú, podvečer sa divajú na sivú vodu Dunaja, [...] nedajú sa krestáanom milovat" (Horváth 2010: 133). 
Podl'a J. Tancera prívlastok orientálny stráca po roku 1918 charakter neželaného a predstavuje výraz záujmu o východnú Európu (Tancer 2013:201).V próze Laco a Bratislava sa tento záujem odráža aj v jednej zo záverečných scén, v ktorej sa Laco a Želka zmierujú. Dvojica pocituje znovuobjavenú vášeň, ktorá prichádza v podobe juhovýchodného vetra a s ním spojených poetických predstáv o orientálnom svete a jeho vášnivom charaktere. Toto zmierenie je zároveň rozlúčkou so Želkou, prebiehajúcou na príznačnom mieste schôdzok dvojíc, v Horskom parku. V Lacovi na nábreží Dunaja pri predstavách o živote za jeho hranicou dozrela myšlienka na odchod, ktorú opät' možno spojit's metaforou iniciačného prechodu cez rieku. $\mathrm{V}$ závere sa pred ním otvára svet $\mathrm{v}$ podobe kruhu ako obraz znovuobjavenej nádeje, s ktorou odchádza z Bratislavy, podobne ako do nej prišiel. Laco ako človek na ceste je sprevádzaný potrebou d'alšieho pohybu, no vyrovnanie mu poskytuje nádej, že sa raz do mesta vráti.

Bratislava zo záveru novely je Bratislavou, s ktorou sú zviazané dve zmiešané emócie: smútok z rozlúčky a zároveň útecha v podobe neurčitej vízie návratu. Návrat možno chápat' aj ako iluzívny, no účinný prostriedok, ktorý robí lúčenie znesitel'nejším. Bratislava sa totiž v prítomnosti spája s nedostatkom istoty či straty skutočného v zdanlivosti rojčenia, z čoho vyplýva jej pohladnicový charakter či impresionisticky prchavá atmosféra. Podobne aj pre Lacovo smerovanie podstatný, no do existenciálnych rozmerov nevyhranený obraz rozporuplnej sociálnej nerovnosti. Horváthova Bratislava predstavuje diapazón najrôznejších štylizácií mesta ako milenky, panny či dekadentne ladenej čiernej dámy, sprostredkovatela zážitkov, mesta-dvojníka, ale aj kontrastného pozadia subjektu, pričom tieto imitácie rôznych literárnych diskurzov sú často utvárané odkazmi na kultúrne etablovanú tradíciu, najmä na iniciačné postupy, žánre románov výchovy a dezilúzie či romantické motívy. Nálada spojená s modernizáciou Bratislavy prechádza od vitalistického opojenia cez ironicko-patetický obraz avantgardných nádejí v znovuzrodenie mesta do skeptickejšie ladenej melanchólie. Atmosféru tiež dotvárajú poetisticky hravé výjavy z bratislavských kaviarní či prechádzok na korze, rovnako je obohatená o exotický závan orientálnych prvkov mesta, ktoré sa stáva priestorom citovej výchovy, nostalgického dojímania, intimity, neurčitej prítomnosti a neistých, ale nádejných návratov.

Štúdia je výstupom grantového projektu VEGA 2/0069/19 „Geopoetika“ Bratislavy: reprezentácie mesta v slovenskej literatúre po roku 1918. Zodpovedný riešitel:

Mgr. Radoslav Passia, Ph.D. Doba riešenia: 2019- 2022. 


\section{Pramene}

HORVÁTH, Ivan, 2010. Laco a Bratislava (Najjednoduchší príbeh). In HORVÁTH, Ivan. Prózy. Bratislava: Kalligram-Ústav slovenskej literatúry SAV, s. 96-152. ISBN 978-80-8101-371-3.

\section{Literatúra}

GIRARD, René, 1968. Lež romantismu a pravda románu. Praha: Československý spisovatel. ISBN 22-104-68.

HODROVÁ, Daniela, 1989. Hledání románu (Kapitoly z historie a typologie žánru). Praha: Československý spisovatel. ISBN 22-016-89.

HODROVÁ, Daniela, 1994. Místa s tajemstvím (kapitoly z literární topologie). Praha: KLP. ISBN 80-85917-03-3.

KUZMÍKOVÁ, Jana, 2006. Modernizmus v tvorbe Ivana Horvátha. Bratislava: Veda. ISBN 80-224-0875-1.

MIKULOVÁ, Marcela, 1998. Mestský živel (u) Janka Jesenského. In MANNOVÁ, Elena, ed. Meštianstvo a občianska spoločnost' na Slovensku 1900 - 1989. Bratislava: Academic Electronic Press, s. 101-109. ISBN 80-88880-20-3.

MINÁR, Pavol, 1998. Mesto v slovenskej medzivojnovej fikcii (predpoklady, pravidlá, kódy a logika produkcie textov). In MANNOVÁ, Elena, ed. Meštianstvo a občianska spoločnost na Slovensku 1900 - 1989. Bratislava: Academic Electronic Press, s. 111-135. ISBN 80-88880-20-3.

SVATOŇ, Vladimír, 2017. Střední Evropa: návrh jiného světa. In SVATOŇ, Vladimír. Na cestě evropským literárním polem. Studie z komparatistiky. Praha: Univerzita Karlova, Filozofická fakulta, s. 106-114. ISBN 978-80-7308-746-3.

TANCER, Jozef, 2013. Neviditelné mesto (Prešporok/Bratislava v cestopisnej literatúre). Bratislava: Kalligram, s. 236-239. ISBN 978-80-8101-665-3.

TRÁVNÍČEK, Jiří, ed., 2009. Zrození střední Evropy z ducha. In TRÁVNÍČEK, Jiří, ed. Vkleštích dějin. Střední Evropa jako pojem a problém. Brno: Host, s. 243-304. ISBN 978-80-7294-323-4.

Mgr. Vladimíra Mravcová

Ústav slovenskej literatúry SAV

Dúbravská cesta 9

84104 Bratislava

Slovenská republika

E-mail: vladimira.mravcova@savba.sk 